(Cyanamid Products, Ltd., London) classified them into those that alter the microbial flora to the benefit of the host animal and those, largely having hormonal activity, that produce increases in growth or productivity by modification of metabolic processes. The former class of compounds was of greater practical importance, and had the largest effect when the level of performance was poor. Detectable quantities of some antibioties given in the diet appeared in the serum. If there was reason to suppose that the beneficial effect of the antibiotic was systemic it was desirable that blood-levels should be increased. If, however, the response to an antibiotic was solely due to modification of the gut flora, such enhancement was unnecessary. The hormonal food additives such as cestrogens and thyroid-active agents could be of use in increasing fat deposition and improving carcass quality, although there was some danger of residues in the tissues if oestrogens were given in the food.

The final paper in the symposium was an enter. taining account by Prof. M. F. M. Meiklejohn (University of Glasgow), speaking in his capacity as editor of Scottish Birds, of wild birds that have been used as food for man. He began by reading from the Book of Leviticus the catalogue of birds that were prohibited as food by Mosaic law, and showed how nearly it corresponded to the list of birds customarily considered as unfit for consumption. The choice of wild birds for human food depended on their palata. bility and the ease with which they could be captured. In general, sea birds were less palatable than land birds, although there were instances of inhabitants of remote islands subsisting on some of the colonial nesting species. Of the land birds, those that lived in flocks and hence were more easily caught in quantity were most frequently a source of human food. Many of the traps and nets used to-day by ornithologists derived from the catching devices evolved long ago for the capture of wild birds for food. Prof. Meikle. john posed a number of questions, which the audience attempted to answer, about the relation between the food of wild birds and their suitability for human consumption.

The lively discussion that followed each of the papers fully justified the choice of subject for this symposium. On this occasion at least, the more homely aspects of the domestic bird were overshadowed by its role in the field of nutritional science. M. E. Contes

\title{
THE EUROPEAN NUCLEAR ENERGY AGENCY
}

\begin{abstract}
7 THE third report of the European Nuclear Energy Agency *, presented to the Consultative Assembly of the Council of Europe by Prof. S. Balke on September 26, records substantial progress in the first joint undertakings. Work on the Eurochemic site was inaugurated in July 1960 and the detailed preproject for the plant was approved in June 1961 . The Halden heavy-water reactor reached boiling in October 1960 with the first fuel charge of natural uranium, and installation of a second fuel charge of enriched uranium will permit a power of $20 \mathrm{MW}$. to be reached before the end of the year: joint operation of the reactor has been extended to the end of 1962 . Construction of the Dragon high-temperature gascooled reactor began in April 1960: civil engineering work on the site is well advanced and supporting research and development are progressing in parallel.
\end{abstract}

A group was set up in November 1960 to study the nuclear propulsion of ships, and a meeting of experts has been convened to determine the areas of nuclear research where particular need for international co-operation exists and the objectives and means of collaboration.

The European-American Nuclear Data Committee, created in June 1959, reviews the measurement programmes of member countries, inventories the equipment available, and has compiled a list of requests for new measurements so as to facilitate collection of the necessary data. It is also assisting countries which have only recently begun to work in this field, and the Agency, in July 1961, decided to establish a European system of supervision and emergeney warning which involves the immediate notification of any abnormal increase in environmental radioactivity recorded in a member country. A study-group on food irradiation was set up in

* Organtzation for European Economic Co-operation-Furopean Nuclear Energy Agency. Third Report on the Activities of the Agency European Nuclear Energy Agency, 1961.)
January 1960 to examine the economic and technical possibilities of the application of food irradiation so as to harmonize national programmes and propose joint projects where appropriate. International seminars for university teachers and technical executives were again organized in 1960 and 1961 , and a specialized symposium on criticality control in nuclear industry at Karlsruhe was attended by one hundred specialists.

The Agency has also undertaken the examination of regulatory, administrative and legislative provisions introduced by European countries to conform with the radiation protection norms adopted in 1959 , and these norms are being revised, in liaison with Euratom and the International Atomic Energy Agency, to take account of the latest recommendations of the International Commission on Radiological Protection. A Convention on Third Party Liability in the Field of Nuclear Energy, dated July 29, 1960, has been signed by sixteen members of the Organization for European Economic Co-operation. The Agency also participates in the investigation of problems posed by the insurance of nuclear risks. and particularly the application of tax regulations governing technical reserves and insurance premiums to these risks. A first set of regulations applicable to research or experimental reactors has been elaborated. by the Control Bureau responsible, under the Agency's Steering Committee, for carrying out the Security Control Convention. In addition, the Agency centralizes economic data bearing on the development of the nuclear industry, and the result of an investigation, published in 1960, predicted that nuclear power stations will provide less than 3 per cent of the capacity of the European electricity production in the coming five years and less than 10 per cent in fifteen years.

The practical value of international co-operation in this field is fully established by the year's work, and the experience gained in co-ordinating scientific work 
shows that in this way the less advanced countries gain indispensable experience that they could not acquire by themselves, while the other countries also benefit. This effort should be continued on as wide a geographical basis as possible, for the value of the results is increased by the scope and variety of the means used and relative costs are reduced. The report emphasizes that this experience in nuclear research is valid in other scientific fields and that European scientific progress calls for a concentration of human, financial and industrial resources only attainable by international co-operation. Annexes to the report include a report on the possibilities of joint European action in nuclear propulsion of ships and L. Kowarski's report on new trends in atomic research and their international significance.

\section{UNIVERSITY FINANCE IN BRITAIN : 1959-60}

\begin{abstract}
HE annual returns from universities and colleges in Great Britain* in receipt of Treasury grants for the academic year 1959-60, now covering twentyone universities and three colleges, is prefaced by a somewhat longer general survey than last year, in which university expenditure on research and academic salaries is considered more particularly.

The University Grants Committee has already made a recommendation to the Chancellor of the Exchequer regarding the location of a fourth new university, in addition to those recommended in July 1960, to be located at Colchester, Canterbury and Coventry, but this location is not disclosed. The Committee considers that the establishment of any new universities beyond these four should wait on the report of the Committee on Higher Education, and meanwhile academic planning boards are being appointed for the Universities of Essex, Kent and Warwickshire. It is expected that the expansion proposed by existing Scottish universities will provide the additional places needed in Scotland by the early 'seventies. Apart from this, the University Grants Committee emphasizes the importance of the enthusiasm and interest of a sponsoring area in determining their decisions on the location of new universities, as well as the presence of industries and some local financial support, the supply of lodgings and the attractiveness of the location to academic staff.
\end{abstract}

Following Sir Arthur Rucker's review of the application by the universitios of the procedures recommended by the Gater Committee, a Building Sub-Committee has been established under the chairmanship of Sir Keith Murray to advise the University Grants Committee on its procedures for assessing non-recurrent grants for building works. A sub-committee has also been set up to assess, and advise the Committee on, the proposals for development in Oriental, African, Slavonic and East European studies which come forward from the universities, and a committee has been appointed with Sir Edward Hale as chairman, to make a comparative study of the methods of teaching undergraduates now being used in the universities and colleges of Great Britain in the fields of arts and pure and applied science. The report was obviously written before the Chancellor of the Exchequer made his statement in July, and it remains to be seen whether and how far the provisional building programme which the Committee has agreed with each of the universities, in the light of the Chancellor's statement on January 25,1961 , for each of the four years 1962-65, will be affected. To meet the expansion to 170,000 students by the early 'seventies and make good the backlog of past years, a building programme of $£ 175$ million

* University Grants Committee. Returns from Universities and Colleges in recelpt of Treasury Grant, Academic Year 1959-1960. Pp. 76. (Cmnd. 1489.) (London: H.M.S.O., 1961.) 4s. 6d. net. at 1960 costs is required. The Committee has no apprehensions on the quality of students expected in the next ten years; it stresses again the importance of halls of residence; it welcomes the attention which the universities are giving to their existing degree structure, including the postgraduate structure, and generally it is impressed and encouraged by the attitude of the universities to the projected expansion.

The report records a solution to the question of assistance for St. David's College, Lampeter, by association with the University College of South Wales and Monmouthshire, which will assume sponsorship for St. David's for a trial period of ten years, during which, from August 1, 1961, the University Grants Committee will consider applications for recurrent and non-recurrent grants.

The number of full-time students in British universities again increased, to 104,009 , compared with 100,204 in 1958-59, and statisties collected in October 1960 show a university population of more than 106,000. There were 6,443 full-time and 2,400 part-time students from overseas within the British Commonwealth, and 4,208 full-time and 2,068 parttime students from foreign countries. Of full-time men students 36.8 per cent were in arts, 24.7 per cent in pure science, 19.7 per cent in technology, and 11.9 per cent in medicine; these figures compare with $36 \cdot 8,24 \cdot 2,19 \cdot 5$ and $12 \cdot 5$, respectively, in 1958-59. For full-time women students the corresponding figures for $1959-60$ are $62 \cdot 0,21 \cdot 1,1 \cdot 3$ and $11 \cdot 8$, respectively, and for 1958-59,62.6, 20.7, 1.0 and 11.9. Full-time advanced students of pure science numbered $4,512(34.5$ per cent); of technology, 2,442 (18.7 per cent); and of medicine, 1,052 (8.1 per cent); 3,585 students were taking postgraduate courses in teacher training.

Of the full-time students, 83,083 wexe reading for a first degree, 3,605 for a first diploma, and 16,649 were engaged in research or other advanced work; the corresponding figures for $1958-59$ were 80,805 , 3,928 and 14,839 , respectively. Of the new full-time students, $25 \cdot 2$ per cent were in pure science, $16 \cdot 0$ per cent in technology and 9.0 per cent in medicine; in 1958-59 the corresponding figures were $24 \cdot 1,16 \cdot 2$ and 8.9 per cent, respectively. Of all full-time students, 76.0 per cent were men and 24.0 per cent women, a proportion practically unchanged from 1938-39, when the corresponding percentages were $76 \cdot 7$ and $23.3 ; 17 \cdot 2$ per cent were at the Universities of Oxford and Cambridge, 20.9 per cent at the University of London, 39.1 per cent at other universities and university colleges in England, 5.9 per cent in Wales and 16.9 per cent at Scottish universities. The proportion of full-time students residing in colleges or halls of residence was 27.0 per cent, 